\title{
Babbage among the insurers: big nineteenth-century data and the public interest ${ }^{1}$ Daniel C.S. Wilson
}

\section{Introduction}

Towards the end of a long life spent in the collection of mortality data, Thomas Rowe Edmonds (1802-1889) entered his own senescence in ill-health and suddenly feared for his financial provision. Despite having served as actuary of the Legal and General Life Assurance company for twenty-eight years -- a company which had grown rich on the sale of insurance policies to those Victorians with the foresight and good sense to take them out -- its own planner-in-chief seemed not to have taken the very steps in his own life that his firm urged so incessantly upon the public at large. In the course of the nineteenth century, financial services developed significantly with many new specialist roles emerging. But as late as the 1860 s, an actuary still provided a uniquely complex function of oversight, with singular responsibility for the health of their company's finances. After successfully stewarding the Legal and General through three decades of recurring crises in the industry as a whole, Edmonds found himself in the strange position of writing nervously to his employers about one final risk: 'I hope that I may not be considered unreasonable in asking for some kind of promise that in case of failing health or other unavoidable cause of retirement', such an 'injurious' scenario would not jeopardise the proper 'allowance or pension bestowed on me in respect of the length of my services as actuary 28 years' (Edmonds, 1865). The nature of this request for sympathy - for 'some kind of promise' - was precisely the kind of awkward personal pleading that insurance, by virtue of its formal contract, was supposed to render unnecessary.

That a luminary of the actuarial scene could find himself in such a position illustrates the specific difficulty of anticipating risk, but also a more general feature of insurance; namely, that it has long served to reveal the often fraught and hidden relations of dependence 
between the individual and the larger group to which they belong. When the knotty social question arises of who will bear the burden of risk - from mild misfortunes to catastrophes insurance has for centuries provided an answer. And of its different forms, insurance on human lives has been the most amenable to mathematical treatment. Unlike the cases of marine, fire or more recently, health insurance, where the feared outcomes may or may not arrive, the case of life assurance - as the British formulation makes plain - involves the conceptually simpler question of when, not if. In the nineteenth century (as both before and after) insurance was associated by its critics with gambling, and by its supporters as the opposite; that is, an offer of certainty in an uncertain world. Whether seen as a gamble or a certainty, the supposedly scientific practice of insurance addressed itself towards the future, equipped with a vast trove of data about the past.

This article explores the question of the public interest in relation to these mass archives of changing human longevity over time. Questions we might recognize today were posed in the nineteenth century about the ownership status of mortality data, how it should be organized, and how to get access to it. Just as historians have highlighted the role of the insurance industry in helping to create modern economies, it has also become a focus of twenty-first-century discussions of privacy and big data (Alborn, 2009; boyd, 2012: 664). A frequently cited concern about indiscriminate data harvesting (alongside the fear of state surveillance) has related to insurance companies. Among the most egregious infringements of privacy is the purportedly relentless desire of insurers to acquire ever more data about lives. The question of whether such a desire is reasonable has been posed by critics of insurance since the early nineteenth century; the answer tends to depend on what one thinks of insurance more generally (Porter, 2000). A loose distinction may here be drawn between those who have felt happy entering into a probabilistic bargain, whether conceiving of such a transaction as a reasonable precaution, an enlightened social good, or even an attractive 
wager. On the other hand might be those made uncomfortable by such a hedge against fate and who have seen insurance as suspicious and in some way intrusive, unfair or even - as early-modern critics held - impious (Clark, 1999).

Actuaries tend to the former view. Indeed, as a profession charged with anticipating the future, they have been omnivorous in their sources of information, having had the most instrumental of reasons for falling victim to archive fever: to predict, and therefore to price, the future correctly (Daston, 2017). The avalanche of numbers at their disposal ranged from those produced by States but also private actors, natural scientists, as well as clerical and municipal initiatives (Hacking, 1990). It is this willingness to employ whatever data have been to hand which has helped to give the insurance business its unresolved status between the private and the public realms, and it is this ambiguity which gives the subject its ongoing interest.

Actuaries developed a form of archival technique -- collecting, manipulating and extrapolating from data -- which allowed the creation of a professional identity; however, this article shows how the knowledge they proffered was mediated and constrained by the institutions in which it was put to work. The laws of large numbers allowed one to predict the fate of the mass, but not that of an individual. This was especially true in the case of Thomas Rowe Edmonds, whose relentless accumulation of data about lifespans did not help in managing the terminus of his own. The irony of Edmonds's position helps to dramatize another key feature of insurance: the large datasets which have given rise to the laws of large numbers, themselves depend on the prior existence of a collective body, either real or projected, on which calculations are conducted; however, the collectivities which benefit from insurance do not necessarily map neatly onto the group of individuals whose data generated them in the first place (still less those who worked on their production). Moreover, the interests of the insuring public and the public-at-large have not always aligned. As a 
technique for confronting risk, insurance has generated new forms of collectivity, with the exclusions and inclusions this entails. The web of relations between these different publics is therefore highly contingent upon historical and technical arrangements (Alborn, 2009; Bouk, 2015). In addition, this article focuses on how the property relations of data were construed in the production of what is here termed the insurance archive. It shows how the idea of the public interest was invoked by advocates of one measure or another, even though its meaning was seldom obvious.

The public interest was of special concern to Edmonds's fellow Cambridge alumnus, the campaigner for open data and occasional actuary, Charles Babbage (1791-1871). This article traces Babbage's work among the insurers and, in particular, presents some novel findings about his foray into the world of life assurance during the 1820s. It sketches the context for Babbage's little-known publication on insurance and by considering actuarial science as a form of archival work at the boundary of natural and human history, raises questions about the politics of large datasets. The notion of the public interest itself has a long history, both as an object for political philosophy, but also as a rhetorical device whose function in insurance discourse bears further examination (cf. McFall, 2007). 'Public interest' has most often been formulated as a democratic bulwark against autocratic government (Gunn, 1989) or in opposition to the idea of a partial (or vested) interest. The earliest companies in Britain had complex relations to the State. Controversial corporate behaviour prompted questions about the public interest and was a factor in companies being incorporated in the first place (Taylor, 2006: 4-8). Eighteenth-century debates centred on whether the public interest consisted in anything beyond the aggregation of private goods. Rousseau thought that it did; a view which became a fundamental credo for later advocates of insurance, whose marketing emphasised that their product was both a practical and also a moral measure. In the context of nineteenth-century liberalism, the public interest became a 
way to reconcile an ambient individualism with a sense of community. In practical terms, such accommodations could be found in the work of 'useful' societies and other nongovernmental actors which were nonetheless involved in forms of public provision. This article focuses on the production of data which might in some sense be considered as public, by actors on this fuzzy boundary. It focuses on private insurers, ad hoc groups of reforming actuaries, celebrated mathematicians and statisticians. The idea of the public interest is useful for exploring the operation of insurance: in the hands of Edmonds and Babbage, it became not only a rhetorical dividing line separating the socially responsible from the rest, but also a tool for advocating fundamental reform of the social contract between the individual and the collective.

The following section situates Babbage and Edmonds in the context of an insurance market which burgeoned during the second quarter of the nineteenth century. Babbage was an instinctual reformer whose zeal for open access to information quickly ran into difficulty in an industry with which he was unfamiliar. An insider, Edmonds nonetheless sought to reform the workings of the archive on which insurance was based for reasons which were not only technical but political. Section three explores the relation between insurance and the State, in its different guises, and considers the ways in which life assurers successfully generated trust. Section four explores in detail Babbage's own venture into life assurance and then traces the critique he published of the industry, which despite its potential for good was said to be failing its customers and the public at large. Section Five examines the institutional efforts of Babbage and Edmonds to improve what might be called the politics of public data, focusing on different initiatives taken respectively at the Statistical Society of London (SSL), where both men were active, and the General Register Office (GRO), on whose operations it is argued Edmonds had an unacknowledged influence. This influence is traced in Sections six and seven, in which we see Edmonds's ambition for insurance data to act as a master key for 
unlocking improvements to public health, which was a political aim that would later be shared by William Farr at the GRO. Edmonds's hope for achieving this was through the discovery of a general law of mortality - a distilled version of all past mortality data - which proved controversial. If the history of insurance is that of an archival science for making predictions, then the article concludes by asking what changes to the nature of this archive might mean for its future: how might the public interest in insurance need to be reconstrued in a time in which the generation and ownership of data has become a fraught political and economic issue?

The selection of a particular insurance technique - as well as the discourse around that choice -- reveals much about the social and economic order; but it also raises questions for democratic politics. If risk management is an unavoidable part of modern life then what influence should the subjects of risk, i.e., the demos, wield over the way that risk is conceived and calculated? With the advent, at the time of writing, of live quantification and real-time dynamic pricing, enabled by wearable and other tracking devices, the traditional practice of risk-pooling may be reaching the end of its useful life (McFall, 2015). As such, digital societies face the open question of how best to organise their systems of insurance. In the early nineteenth century (as in the twenty-first) debates centred on the archive which formed the basis of insurance techniques. Since these data were the basis for computing risks, questions about their composition and use, their ownership and accessibility, have always been political questions. This point was understood by the two protagonists of this article, who believed that they ought not be asked by actuaries and financiers alone.

\section{Babbage \& Edmonds}

'Nothing is more proverbially uncertain' wrote Babbage in 1826, 'than the duration of human 
life, when the maxim is applied to an individual; yet there are few things less subject to fluctuation than the average duration of a multitude of individuals.' (Babbage, 1826: xiv) The self-evident appeal of insurance rested on the power of large numbers, and so it was during the boom of the 1820s that Charles Babbage, in desperate need of money, entered the fray. After a short period working as an actuary for a failed insurance company, Babbage published a little-known book about the life assurance industry: a critique which focused on the choice of dataset being used as well as on the way that information was accumulated, shared and put to work, on the one hand by actuarial experts, and on the other by the companies who employed them. The context in which the book was written was one of national economic drama, with a speculative boom and bust in the financial sector, but it was also one of personal tragedy for Babbage, during which he faced bad luck, business failure and the death of his father, his wife and child; imponderable disasters whose anticipation have long been the spur to insurance schemes of one sort or another.

Like Babbage, Thomas Rowe Edmonds was a graduate of Cambridge's mathematical tripos and understood that accurate insurance relied on access to information about the likely lifespans of a given group of people. This data was assembled with a great deal of effort by actuaries - because the value of consistent record-keeping was not widely apparent - into 'life tables'. The first such table had been published in the Philosophical Transactions by the astronomer Edmond Halley in 1693. Its innovation was to introduce the idea of time series into tabular presentation, its value when applied to insurance was immediately apparent, and its importance as a tool was articulated in 1859 by the statistical pioneer William Farr: 'The Life-Table is an instrument of investigation; it may be called a biometer, for it gives the exact measure of the duration of life under given circumstances.' (Farr, 1859: 717) The suitability of different tables in given circumstances, as well as their reliability and accessibility thus became the focus of debate. 
The challenge of compiling life tables included the problem of human motility. One had either to collect numbers in a longitudinal fashion, tracking the same individuals over long spans of time, which required a consistent and sophisticated bureaucracy of some sort; or, one could look for a settled community, assume a stable population, and take a synchronic measure of the ages at which its members died. The seventeenth- and eighteenth-century progenitors of life assurance used the latter method, focusing on bills of mortality recorded in a given town or village (such as Breslau, Northampton or Carlisle) where migration was thought to be limited. Tables which set out the changing life expectancy for humans at different ages could then be computed, published and circulated for use among practitioners. A radical shift to the former method became possible once institutions for life assurance had been in existence long enough to use their own records to calculate mortality. The world's first actuary is thus said to have been William Morgan, who effectively ran the Equitable Life Assurance Society from 1775 to 1830 . Morgan was nephew to the radical non-conformist Richard Price, compiler of the Northampton Life Table, which he had produced in the course of a long and politicised debate about demography, and which became the standard work for a generation of future actuaries (Buck, 1982).

Debate about the insurance archive can therefore be seen as centring on this question of method: was it best to rely on data derived from an idealized sample that was supposedly representative, or from a company's accumulating experience of mortality? More generally, actuaries, statisticians and mathematicians argued about the best methods for calculating and communicating probabilities. Edmonds and Babbage were prominent in imploring both public and private institutions to improve the quality and the accessibility of their archive so the public could draw their own conclusions. Babbage claimed that unscrupulous insurers used the fact of patchy data to the disadvantage of their customers, while Edmonds spent much of his career attempting to transcend the problem in a quest for the actuarial holy grail: 
a law of human mortality. But whereas Babbage went on to become one of the best-known philosopher-kings of Victorian Britain, Edmonds was treated as a pariah by the elite mathematical establishment and despite myriad scientific and medical contributions died in obscurity.

\section{The Projectile Power of the mind}

As the British economy boomed in the 1820s many new companies formed, expanding the availability of life assurance to new publics. A product that had been the preserve of aristocrats, served by a few venerable corporations in 1800 -- with only about ten thousand policies in force -- quickly gained popularity. A culture surrounding life assurance developed which advanced the idea that it was both a responsible thing to do, and also a lucrative form of savings (Alborn, 2009). Because premiums accumulated compound interest in the hands of the companies, customers were encouraged to imagine the value of their policies growing steadily over time. The sums involved made life assurance companies into powerful institutional investors, providing ready capital for the government as well as for Britain's industrialisation more generally. Concomitantly, a degree of the success of these 'societies' came at the expense of taxpayers, whose bond interest was a major source of their steady growth. The financial relation of insurance corporations to the State has thus been a complex symbiosis of public and private. ${ }^{2}$ Faced with the clear moral hazard of gambling on human lives, the government had legislated in the late eighteenth century (Alborn, 2010) but as the companies never tired of pointing out, there were public benefits to be had from the existence of private insurances. As the sector expanded in the 1820s governments moved with caution and conducted a series of parliamentary inquiries, taking advice extensively, including from Babbage: the mode in which the State might intervene in the public interest was therefore not as clear-cut with regard to insurance as in other sectors (cf. Taylor, 2001). 
Insurers stressed the benefits of their product by emphasising its liberal and enlightenment qualities in harnessing the law of large numbers: 'from this first principle has arisen a system of mutual co-operation, which has almost destroyed the proverbial uncertainty of human existence, neutralized its most bitter consequences, and left it to the free choice of every man to bequeath to his family, penury or independence.' (Eagle, n.d.) The intention to embarrass those men yet to take out a policy was often realised by invoking the spectre of the stricken widow on her way to the workhouse. By the 1830s mainstream journals could lambast such failures of anticipation in public:

[w] hen Life Assurance is as universally understood and practised as it ought to be, he who has not made such a provision, or something equivalent, for the possibility of his death, will, we verily trust, be looked on as a not less detestable monster than he who will not work for his children's bread; and his memory after death will be held in not less contempt. (Anon., 1839)

The means of avoiding such a fate was offered to the public alongside images of solidity and stability: companies were named after rocks and anchors and illustrated with timeless classical architecture alongside boasts of the astronomical sums of capital with which they were backed. These company prospectuses followed a typical rhetorical pattern: life assurance was a modern wonder whose time had come, there was no need to explain its principles (since their supreme value was obvious) but then to explain them anyway.

The Public, it is believed, are now beginning to have a clearer view of the advantages thus held out to them, and are daily learning to have more familiar recourse to the practice of Assurance, $[\ldots]$ one of its most peculiar and interesting features is to be found in this,--that the more widely it is diffused, and the more comprehensive it is made, the more secure and stable does it become, and the more liberal and advantageous are the terms upon which its benefits may be offered to the Public. (Alliance, n.d.)

Whether instituted on a mutual or a private basis, life assurance offered a form of herd immunity, or strength in numbers. Each new policyholder not only conferred a benefit on their own family, but on all the other families as well. In this way, forms of individual insurance could be presented as public goods. Life assurance already relied on the appeal to a 
counterintuitive blend of self-interest and altruistic motives, but in this broadening of the imagined web of beneficiaries, insurers could claim for themselves a degree of public virtue (McFall, 2007).

An Institution having for its object the protection of families from the vicissitudes of fortune $[\ldots]$ must be considered a benefit to the Community, and deserving of being placed in the first rank of the Institutions of the Country. (Family Endowment, n.d.)

The relation of insurers to the public realm, however, was complex because insurance companies owed a deeper debt to the State, its long-standing laws and powers. ${ }^{3}$ To establish themselves as credible, a new temporal horizon as well as a new form of governmentality had to be envisaged for a company. As François Ewald puts it, the problem of guarantees brings into relief the assumption that insurance institutions were permanent: 'Since they are supposed to be providing security, these need to have a quasi-infinite longevity. With insurance one comes to experience a sort of dilation of timescales, stretched out to span not just one generation or lifetime but several.' (Ewald, 1991: 209)

The promotional literature could incorporate such notions of futurity and the infinite into its armoury of persuasion; as implausible as such claims may appear, they illustrate insurers' willingness to engage in a profound degree of moralizing. One prospectus suggested that the capacity to anticipate the future, indicated by the insurance mindset, was the distinguishing mark of civilization itself. The writer of this pamphlet described the indifference towards the future displayed by native American tribes, an attitude he contrasted with that of the Christian, who dwells in a 'rational creation,' in 'which the FUTURE mingles itself more and more with the present, in proportion as we ascend in the moral and intellectual scale.' Attempting to flatter his readers into buying a policy, he claimed that

[t]he sagacious calculation of FUTURE external contingencies distinguishes one man in capacity from another; and the same projectile power of the mind, acting internally by anticipating the arrival of the personal FUTURE, shows to the conscientious man the quality of his actions, reflected in their consequences both to himself and others; while with regard 
to the religious man it may almost be said that the FUTURE is the very region he inhabits. ${ }^{4}$ (Fry, 1840)

The higher level of cognition claimed on the part of the Christian cohered with the vague evangelicalism which pervaded the aspirational British classes, who could thus distinguish themselves from primitive people as well as the working-classes by the performance of such impressive acts of foresight and numeracy. Potential customers learnt how to navigate large tables of data, reading off their ages against the steadily increasing price of buying a policy. These tables acted as a public confirmation of the laws of nature which inducted large swathes of the population into probabilistic reasoning as they calculated their own longevity.

With life assurance, therefore, one could mitigate risk - yet new risks emerged if you chose the wrong company, which is where information became crucial. New entrants in the field were associated by sceptics with risky and speculative innovation. Dozens of insurers either went bust in the crash of 1826 , folded completely, were taken over or involved in highprofile and remarkable scams over the following two decades, which resulted in a series of parliamentary inquiries. ${ }^{5}$ The risk of scandal arose not so much from the use of ill-fitted data for calculating life expectancies as it did from the more mundane problem of corporate mismanagement. For this reason newly founded life assurance companies made efforts to display the composition of their Boards of Directors. The more illustrious and eminent gentlemen one could display at the head of a prospectus, the greater the respectability of the enterprise: Lords, MPs, and gentry, as well as physicians, lawyers and, especially, Fellows of the Royal Society were recruited to lend their names to the different companies, on the basis of unknown inducements. The importance of this outer circle of personnel was as crucial in establishing the reputation of new companies as was their choice of core employees such as the actuary. In constructing the forms of trust necessary to separate customers from their premiums, companies sought to bind expertise to reputation in novel ways, yet it remained 
unclear which of the two attributes would be decisive. Theodore Porter has set out an influential account of numerical expertise understood as a form of trust (Porter, 1995; Alborn, 1994). He suggests that just as numbers offered an objective refuge from the vagaries of subjective judgement, new professionals such as actuaries attempted to emphasise the unique skills essential to their particular expertise. However, the experience of Babbage and Edmonds suggests that trust was not only constructed through expert behaviour, as Porter suggests, but functioned in a more ambient sense in the transacting of insurance. In the highly charged context in which imperfect data were used to price human life, trust was a prerequisite that was mediated by personal reputation more than it was by actuarial science; a frustration that would be the source of Babbage's attack on the insurers among whom he found himself.

\section{Charles Babbage, actuary.}

Babbage's book, published in 1826, was ambivalent towards its subject: although it delivered a detailed critique of the insurance industry, it was a defence of the principle of insurance in general. Babbage sought to expose what he called 'disgraceful practices', and to give the public the information - especially the raw data - to make supposedly more informed choices (Campbell-Kelly, 1994). Assessing its legacy, most Babbage scholars consider the book unoriginal or a strange sideline, yet it derived special force from his personal status and position as an industry-outsider: it was not unusual to find the text still being cited by actuaries half-a-century after its publication.

A young mathematician at the height of his powers and esteem in 1824, Babbage had been granted government sponsorship to pursue the calculating engine. He guarded his time and energy assiduously, which makes it a curiosity that he should dedicate over a year to the research and writing of $\mathrm{A}$ Comparative View. Babbage didn't enjoy the work, in fact, telling 
Herschel he was sick of it and appearing keen to dispense with the topic in order to free his mind of its nagging complexities (Babbage, 1824a). Yet he felt a public duty to finish and publish the book, which involved at least ten-thousand computations, in fact, made twice over due to Babbage losing the finished manuscript when his boat sank in the English Channel. The motivation for writing the book stemmed from Babbage's frustrating encounters with life assurance on both sides of the fence, as a practitioner and also as an Equitable Society policyholder himself.

In 1824 Babbage was approached with a lucrative offer to become an actuary and turned to his friend Francis Baily for advice. Despite having no experience, he was offered a $£ 1500$-a-year retainer by the board of the Protector Life Assurance company, and Baily suggested that Babbage might expect to earn a further $£ 1000$ through private practice. When contrasted with the $£ 450$ which was Babbage’s private income at the time, the prospect of $£ 2500$ was eye-watering. This sum was wildly higher than that being paid at that time even to the most esteemed actuary of all time, William Morgan. ${ }^{6}$ The size of the salary Babbage was offered testifies not only to the scale of the 1824 bubble, but also to the importance of prestige in selling life assurance. Even if its scientific basis was dubious, it was a vital advantage for a company to boast a garlanded mathematician and a Fellow of the Royal Society as its actuary and Babbage was happy to put his credentials to work.

The offer from the Protector was not, however, Babbage's first encounter with insurance: he had previously been in contact with Morgan himself on at least two occasions. From a fragment of correspondence, it seems likely that in 1819 Babbage wrote to Morgan unsolicited, making some form of recommendation with regard to the running of the Equitable Society (Morgan, 1819). More significant was an interaction in 1824, just before Babbage began working for the Protector, when he appears to have applied for a job as assistant actuary at the Equitable. Morgan's role had increased in complexity and he began to 
seek an assistant as well as a potential successor. This attractive opening - working for a highly regarded institution of national importance - was one into which it seems Babbage hoped to insert himself. However, writing to his friend John Herschel, Babbage reported his failure: 'You recollect the Equitable scheme - a few days after you left England I heard that Morgan had procured his son to be appointed assistant actuary and therefore I considered all chance at an end.' (Babbage, 1824) Indeed, two months earlier Morgan had written to the President of the Equitable urging the appointment of his son Arthur as joint (rather than merely assistant) actuary, stressing the vocational nature of his son's apprenticeship, rather than his mathematical brilliance, as a qualification for the main task at hand - indeed the great challenge - for any actuary: to project a longitudinal view in order to ascertain 'the real state of [a] Society' (Morgan, 1824).

Having been rebuffed in his attempt to shape the Equitable from the inside, Babbage would turn his fire on the Society in public. His 1826 book sparked a controversy with Morgan, who took issue with certain factual claims and was prompted to reply in print -- for the only time in his life -- to Babbage's critique. Morgan stood accused of being overly cautious, secretive and mistaken, all of which contributed to the creation of huge levels of surplus capital, as policyholders were effectively being overcharged. Whereas Morgan saw this safety net as vindicating his approach, for Babbage this was inexcusable inefficiency. To what extent he was motivated by personal animus towards Morgan is impossible to say; however, his failed job application was an example of the nepotism which ran against Babbage's belief in the primacy of merit and the smooth transferability of expertise from one domain to another (Babbage, 1864: 481).

On being approached to become the actuary of The Protector, Babbage made 'numerous enquiries' about the board members and confirmed to Herschel that they were 'highly respectable and very liberal in their views' (Babbage, 1824). In retrospect such 
assurances seem naïve, given that the inadequacy of 'character' as a mechanism for guaranteeing financial probity would become a key plank of Babbage's criticism of the industry. The extent to which the composition of such boards depended on elite personal networks is shown by the fact that Babbage was invited to propose further members himself, his acquaintance being sufficient qualification for the role as well as, perhaps, a perk of the job. Being convinced the company would succeed, Babbage sought to secure shares for at least four of his friends, and was approached for shares in the company by others (Colby, 1824).

As the launch date approached, Babbage worked around the clock calculating fresh premium tables. Advertisements appeared in national and regional newspapers, boasting of the $£ 3$ million of private capital which stood behind the new company as well as the several FRS directors including, of course, Charles Babbage. But all was not well behind the scenes. The launch was twice delayed, and then cancelled entirely (Babbage, 1864; Campbell-Kelly, 1994). For reasons which remain unknown - but most likely an argument over principles between Babbage and certain directors - the company folded before it had launched, and he was given a payoff of one hundred guineas for his trouble (Prevost, 1824) ${ }^{7}$. Despite approaches from several other companies, he was sufficiently burnt and annoyed by the experience to turn his back on the world of finance for good (Babbage, 1824b). Babbage's encounter with insurance was a chastening and dispiriting experience; the failure of the Protector Company revealed that a genius for calculation was no guarantee of commercial success. Babbage was unable to countenance an inefficient business which relied on personal prestige above expertise for its decision-making. The surplus capital held by insurance companies came to symbolise this inefficiency and became a focus for his ensuing anger.

With interest rates having soared during the Napoleonic Wars, insurers were able to generate returns on their investments (at the public expense) which vastly outstripped the 
level of mortality indicated by their tables. In this way, the capital - most jarringly-- of the Equitable Society consistently outstripped its liabilities, and so the questions arose of how to define this accumulation (was it a form of profit?) and what do with it. ${ }^{8}$ It was on the technical question of how to divide the surplus that Babbage was most critical. The Equitable was at least distinguished by publishing the amount of surplus it had amassed as well as the method of distributing it (one-third would be rolled over to the next year and two-thirds shared among members). The companies who did not publicise a methodology were, to Babbage, beyond the pale: 'What is the reason' he asked 'for thus concealing from the public a fact with which it is essential for them to be acquainted, in order to judge of the fairness of the terms offered to them?' (Babbage, 1826: 76) Transparency with respect to the surplus was for Babbage a sine qua non for insurance, and the most glaring example of the way nearly all companies fell short of his scientistic ideal of open access to information.

\section{Public Data Politics}

Babbage's critique of insurers was wide-ranging but focused above all on allowing the public to judge for themselves the quality of the archive from which companies constructed their tables. No longer employed in the industry, Babbage could see no reason for all of the data on which premiums were calculated, as well as the basis for dividing surplus, not to be made totally transparent to the public. Certain actuaries such as his friend Joshua Milne made a point of publishing mortality tables to publicise their scientific credentials. William Morgan revealed fragments of the 'Equitable Experience' data in public, from which others (including Babbage) could try to reverse-engineer theoretical tables. However Babbage's commitment to a scientific ideal of openness can seem naïve if he considered it as a remedy for the politics of the boardroom: open data would not in itself transpose a problem originating in the social 
world of finance into one of pure mathematics. Babbage observed bitterly that if company directors were incompetent, dishonest, or both, it made no difference what the actuaries did behind the scenes; opinions most likely informed by his own experience with the Protector. Babbage's impatience with the messy forms of 'trust' constituting the 'public life' discussed by Porter (1995) draws our attention to the real context in which trust between actuaries and the public was necessarily mediated by the company. These artefacts of the financial industry disrupted the sort of frictionless system to which Babbage aspired consistently in the rest of his thought (Schaffer, 1994). Pace advocates of laissez faire, a free market in insurance did not appear to lead to good information exchange because companies were incentivised to keep their data private. It is this privation of data from public view that Babbage found troubling, but for other critics, there was a more structural issue of concern, relating to the public provenance of that information.

All actuaries became reliant on mass projects of data-gathering such as those conducted by the General Register Office (GRO), but had little influence over the design of those projects. Minor tweaks to the census had unintended consequences for users of the data. For no apparent reason, the 1831 census did not enumerate the ages of those living (as had been done in 1821), which made it impossible for actuaries to ascertain mortality rates for a given age group, since there was no total number living to be put into a ratio with those who had died - the definition of a mortality rate. Thomas Rowe Edmonds was especially exercised about this oversight, later reflecting on the paucity of public data in those years, recalling that the task of attempting to establish the ratio of those living to dying in the years up to 1830 was for those in England at least, 'left to the investigation of private individuals who might choose to undertake the task'.(Edmonds, 1832: xxxviii; Edmonds, 1835a: 310; Edmonds, 1866: 16)).

This would change with William Farr's growing influence over the GRO in the mid- 
century; not only because of his famously meticulous and instinctual grasp of statistics, on which many scholars have commented, but also because of his close links to activist actuaries such as Edmonds (Eyler, 2002). The young Farr was heavily influenced by Edmonds and was professionally indebted to him as well. In the radical and reforming climate of the 1830 s, the Statistical Society of London (SSL) was an accessible forum for a provincial of modest background such as Farr, whom Edmonds nominated for membership. Edmonds had quickly risen within the SSL and was the animating force behind a committee on 'Vital Statistics', composed of various reformers, including Babbage, and packed with actuaries (SSL, 1837). The grandiose objective for the committee was to 'collect the Statistics of Life' as the first step towards a reliable set of population data (SSL, 1838; emphasis added). The project was undertaken in recognition, on the one hand, of the unsatisfactory nature of the national effort (with Edmonds having lambasted the government actuary John Finlaison in print for incompetence $)^{9}$ as well as, on the other, of the fact that the richest hoard of numbers lay with existing organisations such as churches, hospitals, asylums but, especially, the life assurance offices.

The motto of the Statistical Society of London -- aliis exterendum ('to be threshed out by others') -- was the sort of attempt to create a depoliticised zone of raw data to have been repeatedly questioned by scholars and activists of statistics (Hilts, 1978; Gitelman, 2013). In the case of the Vital Statistics committee, the ideal was shown to be wishful thinking immediately as the attempt to collate data was obstructed by certain life offices. Edmonds and his colleagues designed standardised tables to send to every office in order to generate a master table of universal experience (SSL, 1838: 15 Feb). A group of actuaries from the same companies became aware of the scheme and suggested they were better placed to do this compiling, as it were, in-house. The statisticians sought to ensure that this parallel collection was being assembled in the right spirit, 'desirous in the first instance of being informed 
whether the experience drawn from the lives collected by the Committee of Actuaries will be made public by them?' (SSL, 1838: 10 May). Some reassurance on this point was offered, but not fully accepted. Of the data collected by the actuaries, the statisticians merely noted their 'hope [that] they will determine to publish the facts Collected as fully as may be useful to the public' (SSL, 1838: 14 Jun). In the event, the project which became known as the Seventeen Offices table was not as universal as imagined and was extremely slow to reach publication. Those hoping to improve their data grew so frustrated that one maverick actuary, Jenkins Jones, managed to steal a manuscript copy of the table and published a pirated version in advance of its eventual release, five years later (Jones, 1843; Alborn, 1994: 444). Jones was motivated by making the public aware that this data did exist but was being kept in private hands, while other tables calculated at the public expense were in possession of the government actuary and yet kept secret. ${ }^{10}$

Jones justified his data dump by appealing to the same arguments about the advancement of science which Babbage had made in 1826. On this account of insurance, there were scientific actuaries such as himself, motivated by a 'disinterested zeal' (Jones, 1843: $\mathrm{x}$ ) and eager to share new data in forms which could be of use to all. On the other hand were those figures in the industry with base motives inconsistent with the progressive founding principles of insurance. Jones cited at length the passage of Babbage's book, in which he had speculated that the outdated Northampton Tables might one day be replaced by a compilation of the records of those insurance offices longest in existence. This material had been out of Babbage's reach, but when it fell into Jones's hands he made it public immediately, and it seems fair to suppose Babbage would have approved wholeheartedly. When figures such as Babbage, Jones and Edmonds referred to the public interest in mortality data, they articulated its nebulous ownership status. A dataset whose object was the public body, and that was collected by public authorities or by private companies citing the public 
benefit of their work, should not serve the partial interests of those companies. Although anybody involved in insurance would have concurred that openness was good for the industry as a whole as well as the science on which was based, it was not so good for any given company, who sought to preserve proprietary elements wherever possible.

\section{The Actuary as Archivist}

The role of the actuary changed between the 1820 s and the 1850 s as the role grew in complexity and responsibilities accreted to one person that would subsequently be shared out among teams of specialists. During this period of incipient professionalisation (and the subsequent formation of the Institute of Actuaries) the actuary was singularly responsible for the overall health of the company's finances -- not just in the present, of course, but projected forward into multiple possible futures. This complex task of representation comprised a series of elements: to establish their potential liabilities the actuary had first, to choose an appropriate dataset on which to base their calculation of future mortality (or if none were deemed suitable, to create one), and then to carry out a fiendishly complex set of extrapolations from the past data; next, to establish their potential income, the actuary had to form a view about the likely rate of return from a wide range of investments made by the company (using their customers' past, present and future premiums), from property to bonds and annuities, all of which were affected by myriad factors including government finances, interest rates and war. Faced with such a number of imponderables, many actuaries tended towards conservatism to ensure that their companies were well protected; yet, an overly cautious approach was unsustainable if it scared off customers with uncompetitively high premiums. Actuaries, therefore, faced a perpetual balancing act which became the hallmark of their professional identity as men of science blessed with a unique form of practical judgement. 
As William Ashworth (1994) has shown, early office-holders included a number of astronomers and mathematicians for whom actuarial science offered sustaining remuneration; but for others, it was a vocation. Thomas Rowe Edmonds applied for the job of actuary to the Legal \& General in 1837 , a year after its foundation, when its first actuary left his role suddenly. Edmonds had already published several works of radical political economy and was an active member of the Statistical Society of London, but was considered underqualified to take on the position ( $L \& G, 1837)$. When initially looking for an actuary the founding directors had approached the government actuary John Finlaison for advice on who to appoint and, naturally, he suggested his son, who struggled to get to grips with the job before resigning. Edmonds had, however, published in 1832 what he claimed to be an original discovery in actuarial science: a law of mortality (Edmonds, 1832a). The book lamented the paucity of data on which life tables were based and sought to set life assurance on a surer footing, using a combination of Joshua Milne’s 1812 'Carlisle Table', a collection of observations from Sweden, a French convent and Glasgow. From these, Edmonds produced what he called a mean table, which corrected for various errors and biases in the previous tables, as he saw them (Edmonds, 1832a: xiv). Those tables did not properly account for the effects on mortality produced by geography, class, occupation and, most importantly, 'selection': an artefact of the particular group of which the data is a sample, in this case the longer lives enjoyed by those who had taken out life assurance.

Edmonds used interpolation to create a formula for mortality expressed in terms of three newly 'discovered' constants, pertaining to the 'three grand divisions of life', namely, 'infancy, manhood and old age'. ${ }^{11}$ Edmonds conceded that these had already been highlighted by Richard Price in the mid-eighteenth century, but claimed that it had not occurred to Richard Price that these were mathematical constants which applied universally across space and time. Edmonds then used this newly discovered law to recalculate a fresh set of tables 
which he published in full. The result was the audacious claim to have turned the observed regularities of mortality data into a law, which in turn, could be further buttressed and refined by new observations as they became available. Edmonds believed he had produced a powerfully circular and self-reinforcing set of tools for calculating human longevity, and challenged readers to select any mortality table (because every table had its partisans) and check if it conformed to his law. Any deviations could be put down to local causes and the need for better, more refined data: a quest to which Edmonds dedicated much of the rest of his life. For Edmonds, therefore, the insurance archive -- namely, all past mortality experience -- was the bedrock on which his predictive law would be built.

\section{The Law of Mortality}

The love of life being the strongest of human passions, the most interesting of all laws ought to be the law which regulates the rate of decrement of human life from the time of birth until extreme old age. (Edmonds, 1866: 1)

Despite this injunction, the quest for a law of mortality holds a peculiar position within the history of actuarial science. Benjamin Gompertz was widely credited by actuaries as having 'discovered' the law in his 1825 paper in Philosophical Transactions, but his formula was not widely employed in practice (being described as 'almost totally inaccessible' to actuarial students by Porter (1854: 115); Gompertz, 1825). Gompertz's law operated at a high level of generality, leaving open difficult questions of when precisely mortality changed, not least because of the endless perturbations of any specific dataset. Its significance was, rather, to indicate the kind of underlying regularity in human science that was being sought (and found) at that time in the physical and natural sciences. For Edmonds, the law of mortality he 
discovered independently in 1832 provided a recursive framework for ever-greater precision. Every new set of observations served to confirm his theoretical law of mortality still further, while securing his discovery of the fixed and universal constants which determined it. In The Lancet in 1835, Edmonds urged physicians to take an interest in mortality, it being the obverse of vitality and thus a yardstick for measuring medical interventions. Edmonds situated his innovation in relation to Richard Price's insight that mortality varied markedly across the three stages of life:

Dr. Price never attempted to express in numbers the glimmering of truth which had thus evidently flashed on his mind. I am now enabled to state the precise numbers which nature invariably uses in the regulation of her operations. In infancy the annual decrease in the ratio of deaths is 32.4 per cent.; during the 'procreative period' the annual increase in the ratio of deaths is 2.991 per cent. After the procreative period, the annual increase in the ratio of deaths is 7.969 per cent.

If enough data were made public there was the possibility of complete convergence of completing the circle -- between the growing archive of improved observations and Edmonds's algebraic predictions, which could be cross-checked against the widest possible range of samples and cohorts. The most dramatic expansion of data came with the 1849 report of the Registrar General, in which Farr broke down mortality into smaller units across the country than ever before (Farr, 1849). To Edmonds's delight, the theoretical tables he had constructed were consistent with the mortality experience of village, town and city populations (Edmonds, 1850: 300).

Edmonds's approach was thus to bind an ever-improving archive of historical data to the quest for a theoretical law of mortality. His little-known medical publications of the 1830s pointed to the utility of this approach in understanding not only mortality but also morbidity as phenomena of cohorts - which had always been the stock-in-trade of life assurance. Edmonds and Farr shared in adopting this population-level perspective: an insurantial technique which generated new insights, especially when coupled to a radical 
political vision. Edmonds lamented the fact that while a great deal of information had been accumulated about the longevity of well-heeled life policyholders, little was known about those at the sharp end of nineteenth-century mortality statistics: labourers, slum-dwellers, immigrants. The positions Edmonds adopted in his 1828 book of political economy are rightly described as proto-Marxist, with his views on value and labour providing a clue as to his deeper motivation: a universal law of mortality could be used as a diagnostic tool to discover whether certain people were dying more than they should be (Edmonds, 1828; Beer, 1919). Comparing datasets, discovering clues and forming hypotheses about causes -- the innovative method which would later form the basis of William Farr's famous epidemiology - was in fact an insurance technique developed to apprehend trends at a scale beyond simple observation. It should not therefore be surprising that Edmonds was drawn into life assurance: writing five years before becoming an actuary, he described this 'most beautiful application of the science of probabilities to the affairs of life', as a way to ameliorate the condition of the working class as 'all are brought within the circle.' (Edmonds, 1832a: 213ff) Life assurance should be set up by public authorities, suggested Edmonds, because it would inculcate good habits of saving among labourers, and in the process would feedback further advantages, in the form of yet more data:

suitable tables might easily be framed, with very little trouble, to meet all ordinary cases; and a most valuable collection of facts be obtained, relative to births, marriages, and deaths, the period of natural longevity, and all such interesting questions, which would compensate for any little inconvenience [...] in keeping the books, and attending to the general execution of the measure. In a short time this country would possess an accumulation of curious and truly useful statistical facts, serving as a never failing guide for the solution of many important points (Edmonds, 1832a: 214-215).

The intellectual link between Edmonds and Farr is important to acknowledge: they shared a method and also a motivation, the legacy of which can be seen in the history of the GRO, while the biographical connection between the two is borne out in the controversy relating to the provenance of Edmonds's law. 
Babbage had toyed with the idea of producing a law of mortality but it was Gompertz who in 1825 first published an algebraic expression which could solve for mortality at a given age. Edmonds's Discovery of a numerical law regulating the existence of every human being (1832) mentioned Price and Gompertz as predecessors but staked its claim to novelty on the strength of the data which allowed the three constants identified by Gompertz to be computed: 'At present, I think that there are no observations strong enough in accuracy to contend against the apparent universality of the Theory' (Edmonds, 1832: xvi). Edmonds took Gompertz's silence on the issue to mean that he accepted that his law had been superseded, but Gompertz's friends -- above all the Professor of Mathematics Augustus de Morgan (1806-1871) -- took offence on his behalf, accusing Edmonds of plagiarism, and mounting a campaign against him which lasted decades. Edmonds made repeated claims for the novelty and universality of his law which perhaps antagonised certain colleagues. The first issue of the journal published by the Institute of Actuaries in 1851 featured an essay attempting to adjudicate, which gave Edmonds credit for doing the kind of gruelling work that more elevated mathematicians (such as Gompertz) perhaps shirked. However, the author remarked wryly that although Edmonds's priority claim was well known, the ongoing weaknesses in the available data, as well as the inevitable errors and subjective judgements involved in its interpretation, made it difficult to advance a universal law of mortality (Brown, 1851).

In the margin of his copy of Edmonds's 1832 Life Tables, De Morgan wrote: 'All the principle of this discovery, and the resulting formula, is taken with a miserably evasive acknowledgment (amounting to falshood [sic]) from the writings of Benjamin Gompertz' and in the frontispiece De Morgan pasted a four-line ditty which read: 'Little Tommy Tittlemouse/Lived in a little house;/He caught fishes/In other men's ditches' (De Morgan, n.d.). Given that Gompertz did not seem to bear Edmonds ill will -- accepting Edmonds's 
invitation to join the Vital Statistics committee of the SSL in 1837 -- it is hard to make sense of the reason for De Morgan's hostility. Edmonds understood his enterprise as being different to Gompertz's: he wanted a concrete law that could be used in practice, composed of constants derived from empirical observation. De Morgan was preoccupied with the novelty of the mathematics, whereas Edmonds understood himself to be creating a novel tool. The consequences for Edmonds were serious, whose nomination to the Royal Society was vetoed on at least six occasions, almost certainly at the behest of De Morgan. ${ }^{12}$ Edmonds expressed his shock at the experience in correspondence to Farr (who had nominated him to the Royal Society, by that time having far overtaken him in eminence) and after several rounds of combat, Edmonds emerged damaged and diminished from the encounter (Edmonds, 1859: 22-24). Perhaps it was Edmonds's propensity to overstate the importance of his discovery which so irritated De Morgan, perhaps it was his radical views, his gauche manner, or something else entirely (Alborn (1994: 454) describes the campaign against Edmonds as part of a proxy war by certain actuaries against William Farr). Farr went out on a limb for Edmonds: beyond his repeated nominations to the Royal Society, he praised his work in his publications for the GRO and also cited him when authoring reference works on insurance and statistics, but this made little difference to his standing (Farr, 1837). The attacks on Edmonds by members of the mathematical establishment appear disproportionate: acts directed at a perceived troublemaker which undercut any hopes of a legacy for his work.

The practical merits of a law of mortality were of a kind that both Babbage and Edmonds understood: reducing the repetitive labour of computing tables would make the calculation of life contingencies more economical and, even, algorithmic. Aside from the glory of the discovery, its importance lay in being a marker of that regularity which promised that the reams of disorderly mortality data might at base be legible. The generalisation of data into 
laws has been a staple of scientific aspiration and one that fitted Edmonds thought-style very closely. Following the publication in 1847 of Henri Victor Regnault's French government report on the laws of steam, Edmonds embarked on a series of elaborate calculations based on previously published experimental data in order to derive a new formula representing the laws governing pressure, density and heat in terms of temperature. Edmonds's aim was to take the exhaustive experimental data Regnault had provided, to establish a fixed relation (in this case, roughly, geometric) and by interpolation to improve on the existing formulae, which had been subject to decades of debate, from the time of Dalton to that of Kelvin.

What remains to be desired is, the knowledge of the law which connects together the experimental results, and which will enable a person to determine by calculation the elastic force at every other temperature from the known elastic force at any one temperature. (Edmonds, 1865a: 170)

It is unclear precisely what motivated Edmonds to embark on this work. However, this case study provided him with the chance to demonstrate in a different domain his technique of using meticulously collected data to create increasingly accurate iterations of predictive formulae. The two papers on physics were published in consecutive issues of the Philosophical Magazine and were then followed by a third paper announcing yet another 'new formula' for human mortality (Edmonds, 1865b; 1866). These three papers were subsequently extracted and published separately in a single volume and amounted to a statement of methodology (Edmonds, 1866a). In the paper on human mortality, Edmonds produced two new formulae expressed in terms of vital 'force' and explained that:

Both formulae are similar to the formula which has been shown to represent the law, according to temperature, of the elastic force of steam of maximum density, and the formula which has been shown to represent the law of density of saturated steam [...] All four formulae are deduced -- from a differential of the form following:-- (Edmonds, 1866: 5) 
[Insert Fig. 1]

$$
d \cdot \log \mathrm{P}=\alpha\left(1+\frac{t}{a}\right)^{-\frac{1}{k}} d t
$$

The problem Edmonds tried to overcome with his endless iteration and feedback of new data was that his algebraic functions worked perfectly between certain ranges of inputs but not others, meaning that the curves contained different contradictory branches depending on the choice of constant (Edmonds, 1866: 4). Mortality data was rough and partial to such a degree that it was impossible to find any simple algebraic formula that captured the entire range of ages and, so, the qualification ceteris paribus was needed to an extraordinary degree when using it. This led Edmonds to introduce awkward distinctions between 'true' laws and 'empirical' laws, which included specific modifications to account for endless anomalous phenomena. Laws of nature have been assessed in the philosophical tradition of JS Mill, Frank Ramsey and David Lewis according to their competing virtues of strength and simplicity (Carroll, 2016). Edmonds sought a strong law of mortality which could incorporate the full range of human existence, but this came at the cost of simplicity. Although Farr made productive use of Edmonds's laws (and cited him regularly), they did not find wide reception beyond his loyal and famous old friend. Despite the increasing mathematicisation of insurance ever since, actuaries have not sought a predictive law for mortality; preferring instead more elaborate, yet ultimately traditional, forms of risk pooling. As Babbage knew, no archive of past mortality data can predict the span of a single life. And to do so would render insurance impossible; however, the prospect of predictability has returned in a new guise - based not on a law of nature, but on a personalised archive, more detailed and informative than Edmonds could possibly have imagined. 


\section{Conclusion: Past Futures}

On François Ewald's account, society itself is a technique of risk reduction. 'Insurance' implies institutional forms but remains an abstract technology. That is to say that the specific form taken by that technology is not entailed by the institution alone but by the context in which it exists and the aims of its users (Ewald, 1991). Despite the enlightened intentions of theorists such as Thomas Rowe Edmonds, as well as eighteenth-century predecessors such as Price and Condorcet -- for whom it was a tool for ending poverty (Stedman Jones, 2004) the political status of insurance has remained ambiguous because it has been deployed so extensively in securing both private and public interests.

This article has shown how arguments about the public interest were used in different ways by advocates both of private insurance provision (Babbage) and also of public data gathering (Edmonds). These arguments highlight an underlying feature of insurance seldom acknowledged that by virtue of the collectivities it generates, as well as its symbiotic financial relation with the State, it has always been characterised by a complex interdependence of the public and the private. This dependence has not only flown in one direction: this article has also emphasised that the methods used by the great statistician of public health at the GRO, William Farr, were influenced by the techniques of life assurance and, in particular, the approach of his mentor Edmonds. This approach was to distil the best possible archive of mortality data into an ahistorical law. However, the archives of mortality assembled by private insurers were limited in their purview to specific groups of people. Edmonds's political radicalism produced the insight that if this purview could be broadened, the diagnostic benefits would flow to an expanded public-at-large, and so it provides the link between these private collections of data and the universal ones towards which Farr aspired. The work of Farr and Edmonds thus advanced in tandem - as Farr made new forms of data 
publicly available -- and their lasting connection can also be found in the personal support Farr gave to Edmonds during his struggles of the 1850 s and ' 60 s.

Whether particular insurance schemes have been seen as progressive or regressive, arguments about the fairness of a given scheme have turned on the data on which it is founded. ${ }^{13}$ This article has invoked the notion of an insurance archive to highlight the centrality of these data collections on which any insurance must depend. Judgements about that data may relate to its quality - a desideratum for Edmonds -- but also its scrutability which motivated Babbage, and for whom openness and transparency were fundamental to evaluating any scheme of risk management. Historians have sought to explain 'the appeal of insurance', in the face of its counterintuitive offer of deferred benefit (Clark, 2010). The ongoing appeal of insurance schemes into the future will depend to some extent on the willingness of the public to continue pooling risk. Purchasers of insurance may raise such questions not only as: 'is it worth it?' but also: 'is it open?' and 'is it fair ?' - considerations which, in different forms, were central to the debates on life assurance as it developed in the second quarter of the nineteenth century, and on which this article has focused. New techniques such as wearable devices today have the potential to undermine traditional methods of risk pooling altogether by generating information it would be unfair to withhold from other members of the pool, to take just one example of the challenges facing an industry whose success has been based precisely on limiting access to its archive of such data.

The idea of gamifying risk through innovative incentives is not new. Rituals of nineteenth-century insurance such as distributing surplus in the form of the bonus were used to entice customers and, as Alborn puts it, 'offering them opportunities to back their own lives against the experts who had set the odds' (Alborn, 2009: 305). In ways reminiscent of Edmonds and his quest to increase the store of data by which mortality was calculated, today's insurers are pushing for ever greater access to the digital traces that might help 
enumerate the chances of life and death. Nonetheless some things are new under the sun: while past insurers may have sought to influence human behaviour, for instance by insisting on temperance, or some other pro-social virtue, the extent of surveillance at today's insurers' disposal is unprecedented. If insurance is to continue playing its fundamental role in our dealings with uncertainty, the new forms of incentives and penalties it employs may need to be evaluated under a wholly new regime of fairness. This would include considering the ownership of the vast new archives of data, generated by the 'public' and on whose basis new judgements about risk will be priced. Traditional strategies of seeking safety in numbers are only rational under conditions of relative ignorance. With modern techniques of surveillance, such as the wearable devices which quantify selves, the epistemic lacunae which create the conditions for probabilistic insurance in the first place risk unravelling completely in an age characterised by a maximal personalised archive which entails total predictability. In such a context one might ask whether it is even possible sustainably to operate forms of insurance which are freely bought and sold; at least while maintaining the claims, as many Victorians had it, that buying insurance was self-evidently in the public interest.

\section{Bibliography}

Alborn, T. L (1994) A Calculating Profession: Victorian Actuaries among the Statisticians. Science in Context 7(03): 433-468.

Alborn, T. L. (2009) Regulated lives: life insurance and British society, 1800-1914. Regulated lives: life insurance and British society, 1800-1914, Toronto: University of 
Toronto Press.

Alborn, T. L. (2010) 'A Licence to Bet: Life Insurance and the Gambling Act in the British Courts'. In The Appeal of Insurance, (ed. Clark, G. et al.) Toronto: University of Toronto Press.

Alliance (n.d.) Prospectus of the Alliance Assurance Company. Archives of the Institute of Actuaries.

Anon. (1837) 'National Statistics: On the Incapacity of the Statistical Officers Employed by the English Government', British Medical Almanack: 176-80.

Anon. (1839) 'Life Assurance', Chambers's Journal, 373, 23 March.

Ashworth, W. J. (1994) The calculating eye: Baily, Herschel, Babbage and the business of astronomy. The British Journal for the History of Science 27(4): 409-441.

Babbage, C. (1824) Babbage to Herschel, 18 May. Herschel Papers, f.196. Archives of the Royal Society.

Babbage, C. (1824a) Babbage to Herschel, 10 Oct. Herschel Papers, f.198. Archives of the Royal Society.

Babbage, C. (1824b) Babbage to Whitmore, 6 December. BL Add. MSS 37182, f.134.

Babbage, C. (1826) A Comparative View of the Various Institutions for the Assurance of Lives. A Comparative View of the Various Institutions for the Assurance of Lives, London: Mawman.

Babbage, C. (1864) Passages from the life of a philosopher. London: Longman. Bouk, D. (2015) How Our Days Became Numbered: Risk and the Rise of the Statistical Individual. Chicago, 2015.

boyd, d. and Crawford. K. (2012) Critical Questions for Big Data. Information, Communication \& Society 15(5): 662-679. 
Brown, S. (1851) On a general method of approximation to the Values of Annuities and Assurances, The Assurance Magazine 1: 20-40.

Buck, P. (1982) People Who Counted: Political Arithmetic in the Eighteenth Century. Isis 73(1): 28-45.

Campbell-Kelly, M. (1994) Charles Babbage and the assurance of lives. IEEE Annals of the History of Computing 16(3): 5-14.

Carroll, J. W. (2016) Laws of Nature. In Zalta E. N. (ed.), The Stanford Encyclopedia of Philosophy. https://plato.stanford.edu/archives/fall2016/entries/laws-of-nature/ (accessed 13 August 2017).

Ciepley, D. (2013) Beyond Public and Private: Toward a Political Theory of the Corporation. American Political Science Review 107(01): 139-158.

Clark, G. W. (1999) Betting on lives: the culture of life insurance in England, 1695 1775. Manchester: Manchester University Press.

Clark, G.W. et al. (2010) eds. The Appeal of Insurance. Toronto: University of Toronto Press.

Colby, C. (1824) Colby to Babbage, 22 April. BL Add. MSS 37182 f.120.

Daston, L. (2017) 'Third Nature', in Science in the Archives: Pasts, Presents, Futures, ed. by Lorraine Daston. Chicago: University of Chicago Press.

De Morgan, A. (n.d.) [DeM] L.4 [Edmonds] SSR, De Morgan Papers, University of London Library Special Collections.

De Morgan, A. (1838) An essay on probabilities, and their application to life contingencies and insurance offices. London: Longman.

De Morgan, A. (1860) On an unfair suppression of due acknowledgment to the writings of Mr. Benjamin Gompertz. The Assurance Magazine 9(2): 86-89.

De Morgan, A. (1861) De Morgan to Airy, 8 July. De Morgan Papers. University of 
London Special Collections.

Eagle (n.d) Prospectus of the Eagle Assurance Company. Archives of the Institute of Actuaries.

Edmonds, T. R. (1828) Practical moral and political economy. London: Wilson.

Edmonds, T. R. (1832) An enquiry into the principles of population: exhibiting a system of regulations for the poor. London: Duncan.

Edmonds, T. R. (1832a) Life tables, founded upon the discovery of a numerical law regulating the existence of every human being. London: Duncan.

Edmonds, T. R. (1835) On the Mortality of the people of England. The Lancet 24(614): 310-316.

Edmonds, T. R. (1850) An inquiry into the law which governs the mortality of the people of England. The Lancet 55(1384): 297-301.

Edmonds, T. R. (1859) Edmonds to Farr, 6 April. Farr Collection, Volume 1. LSE Archives

Edmonds, T. R. (1860) On the Discovery of the Law of Human Mortality, and on the antecedent partial Discoveries of Dr. Price and Mr. Gompertz. The Assurance Magazine and Journal of the Institute of Actuaries 9(03): 170-184.

Edmonds, T. R. (1865) Letter to Board of Directors, 15 May, Board of Directors' Minute Book, Vol 19, Legal \& General Archives, LMA CLC/B/144/MS33437/019, f127.

Edmonds, T. R. (1865a) 'On the Elastic Force of Steam of Maximum Density', Philosophical Magazine Series 4, 29(195): 169-88.

Edmonds, T. R. (1865b) On the law of density of saturated steam expressed by a new formula. Philosophical Magazine 30(200): 1-11.

Edmonds, T. R. (1866) On the law of human mortality expressed by a new formula. Philosophical Magazine 31(206): 1-21. 
Edmonds, T. R. (1866a) On the Laws governing Human Mortality, pressure of saturated steam, and density of saturated steam. London.

Equitable Society (n.d.) Special Court Minute Book. Archives of the Institute of Actuaries.

Ewald, F. (1991) Insurance and risk. In: Gordon C, Miller P and Burchell G (eds.) The Foucault effect: studies in governmentality, Chicago: University of Chicago Press.

Family Endowment (n.d.) Prospectus of the Family Endowment Society. Archives of the Institute of Actuaries.

Farr, W. (1837) 'Vital Statistics'. In A Descriptive and Statistical Account of the British Empire, edited by J. R. McCulloch. Vol. 2. London: Longmans.

Farr, W. (1849) Appendix to ninth annual report of the Registrar-General of Births, Deaths, and Marriages, Parliamentary Papers 1849.

Farr, W. (1859) On the Construction of Life-Tables; Illustrated by a New Life-Table of the Healthy Districts of England. Proceedings of the The Royal Society 9: 717-721.

Fry, A. (1840) Pocket Diary of The National Endowment. In: Saint-Clair W (ed), Popular View of Life Insurance. London.

Gitelman, L. (2013) ed. 'Raw data' is an oxymoron, Cambridge MA: MIT Press.

Gompertz, B. (1825) On the Nature of the Function Expressive of the Law of Human Mortality, and on a New Mode of Determining the Value of Life Contingencies.

Philosophical Transactions 115: 513-583.

Gunn, J. A. W. (1989) 'Public Interest', in Political Innovation and Conceptual Change, Ball, T. et al. (eds.) Cambridge: Cambridge University Press.

Hacking, I (1990) The Taming of Chance. Cambridge: Cambridge University Press. Halley, E. (1693) An Estimate of the Degrees of the Mortality of Mankind, Drawn 
from Curious Tables of the Births and Funerals at the City of Breslaw, Philosophical Transactions 17: 596-610.

Hilts, V. L. (1978) Aliis exterendum, or, the Origins of the Statistical Society of London. Isis 69(1): 21-43.

Jones, J. (1843) A series of tables of annuities and assurances calculated from a new rate of mortality amongst assured lives. London: Longman.

L\&G (1837) Board of Directors Minute Book vol. 2, f154, 2 May. Archives of the Legal \& General Assurance Society Ltd. London Metropolitan Archives, CLC/B/144/MS33437/002.

McFall, L. (2007) The Disinterested Self. Cultural Studies 21(4-5): 591-609.

McFall, L. (2015) 'Is Digital Disruption the End of Health Insurance? Some Thoughts on the Devising of Risk'. Economic Sociology 17 (1): 32-44.

Morgan, W. (1819) Letter to Babbage, 22 October. BL Add. MSS 37182 f.173.

Morgan, W. (1824) Morgan to The President of the Equitable Society, 8 March. Special Court Minute Book, p10. Archives of the Institute of Actuaries.

Morgan, W. (1833) The deed of settlement of the Society for Equitable Assurances on Lives and Survivorships. London.

Porter, H. W. (1854) On some points connected with the Education of an Actuary. The Assurance Magazine 4(2): 108-118.

Porter, T. M. (2000) Life Insurance, Medical Testing, and the Management of Mortality. In: Daston, L. (ed.), Biographies of scientific objects, Chicago: University of Chicago Press.

Porter, T. M. (1995) Trust in numbers: the pursuit of objectivity in science and public life. Princeton: Princeton University Press.

Prevost, W. (1824) Prevost to Babbage, 29 July. BL Add. MSS 37182 f133. 
Schaffer, S. (1994) 'Babbage’s Intelligence: Calculating Engines and the Factory

System'. Critical Inquiry 21 (1): 203-27.

Select Committee (1827) Report on The Laws Respecting Friendly Societies.London: HMSO.

SSL (1837) Archives of the Statistical Society of London, General Minute Book, $1837-8$.

SSL (1838) Minutes of the Committee of the Statistics of Life. Archives of the Statistical Society of London.

Stedman Jones, G. (2004) An end to poverty? A historical debate. London: Profile.

Taylor, J. (2001) 'Private Property, Public Interest, and the Role of the State in Nineteenth-Century Britain: The Case of the Lighthouses'. The Historical Journal 44 (3): 749-771.

Taylor, J. (2006) Creating Capitalism: Joint-Stock Enterprise in British Politics and Culture, 1800-1870. London: Royal Historical Society.

Taylor, J. (2011) Numbers, Character and Trust in Early Victorian Britain: The Independent West Middlesex Fire and Life Assurance Company Fraud. In: Crook, T. and O’Hara, G. (eds.) Statistics and the public sphere, New York: Routledge.

\footnotetext{
${ }^{1}$ The author gratefully acknowledges the support of the Agence National de la Recherche (PROFUTUR), the Centre de Recherches Historiques at EHESS in Paris, and CRASSH in Cambridge; but especially Rowan Boyson, Frédéric Graber, Boris Jardine, David Raymont, Simon Schaffer and David Vincent.

${ }^{2}$ This point is made by Augustus De Morgan (1838: 257) where he discusses the peculiar perils to insurers of changing rates of bond interest.

${ }^{3}$ The role of the State in securing private enterprise has a burgeoning recent literature in relation to various sectors, e.g. Ciepley (2013) prefigured more radically with specific relation to insurance in Ewald (1991).

${ }^{4}$ I was originally directed to this source by Tim Alborn.

${ }^{5}$ For example the Select Committee (1827), to which Babbage gave evidence. See Taylor (2011) for the most outrageous example.

${ }^{6}$ Morgan earned around $£ 700$ at this time, receiving a payrise to $£ 1000$ in December 1826. (Equitable Society, n.d.: 220) Thomas Rowe Edmonds would be paid $£ 450$ in 1837.

${ }^{7}$ Clues to the breakdown can be found in correspondence with his friend and patron
} 
Lord Somerset. Babbage undoubtedly revealed to Somerset the true reason for the company's collapse but the relevant letter is to the best of my knowledge lost. 20-21).

${ }^{8}$ Richard Price himself had noted this discrepancy as early as 1776 (Morgan, 1828:

${ }^{9}$ First in his book (Edmonds, 1832: xiv), under a pseudonym (Anon, 1837) in a journal edited by Farr, and finally in The Lancet (Edmonds, 1837) when he 'threw off his mask'.

${ }^{10}$ Jones also published a petition by a group of eminent actuaries (including Edmonds) requesting Parliament make public John Finlaison's tables. (Jones, 1843: xxvii$\mathrm{xxx})$.

${ }^{11}$ This is a geometric formula involving a constant which allows prediction of the 'force of mortality' (i.e., a differential function) actually at work at any given age (Edmonds, 1832a: vi). A priority dispute with Benjamin Gompertz flared up over this law, which would return to haunt Edmonds, discussed below.

${ }^{12}$ Bulloch's Roll, Royal Society archives. Edmonds was nominated unsuccessfully in 1858, 1859, 1860, 1861, 1865 and 1866.

${ }^{13}$ For an especially fraught example in the US context see (Bouk, 2015). 